\title{
PENGOLAHAN DAN PENERIMAAN PRODUK KEDELAI PADA RUMAHTANGGA DI PERKOTAAN DAN PEDESAAN PULAU J AWA INDONESIA
}

\author{
(Household's Processing and Acceptance Level of Soybean Products \\ in Urban and Rural Areas in J ava Island, Indonesia \\ Rina Yenrina ${ }^{1}$, Yuliana ${ }^{2}$ dan Deddy Muchtadi ${ }^{3}$
}

\begin{abstract}
ABST RACT
The study was aimed to get data on kind of processing and acceptance level of local soybean products in rural and urban areas in J ava Island. The study locations were South J akarta (Province of DKI J akarta); Serang and Tangerang (Province of Banten); Bekasi, Bogor and Bandung (Province of West J ava); Purwokerto, Semarang and Solo (Province of Central Java); Yogyakarta (Province of D.I.Yogyakarta); Malang, Jember and Surabaya (Province of East Java). The study was a part of a grand study on processing, acceptance, and consumption pattern of local soybean products at various socio-economic level of households in Java Island in 2005. The data were obtained by interviewing and observing 2080 households (consisted of 1280 households in urban and 800 households in rural areas) selected randomly. Soybean products that mostly found in the market and consumed by households of Indonesian people, particularly in J ava Island, were tempe, tauco, soy-sauce, tofu, tofu-flower, soy-sprout, and oncom. The mostly ways to process the soy products were stir-frying, deep-frying, toasting, boiling, and 'bacem'. Besides, there were also some soy products that consumed directly at a household level after factorized processing, namely as soy-sauce and soy-milk. The average time used to process the soy-products varied, depended on the way of processing and number of the product processed. Stir-frying, especially for tempe, tofu, and tauge, was a frequent way done by poor and rich households, both in urban and rural areas. The products that mostly processed by frying in rural household was tempe, tofu and soybean, meanwhile in urban areas were only tempe and tofu. The everage time used by urban households to fry the soy-products was shorter than time used by rural households. It was found that more than $90 \%$ of households in rural and urban areas stated "like" and "like very much" tempe, tofu, and soy-sauce. However, the acceptance level of household on tauco, soy-milk, and soy-flower was still low, namely less than $50 \%$
\end{abstract}

Keywords: handling, processing, acceptance, soy-products.

\section{PENDAHULUAN}

\section{Latar Belakang}

Kedelai (Glycine max (L) Merril) dinamai bermacam-macam seperti; Miracle Golden Bean, the Golden Nugget of Nutrition, the Cow of China, Meat of the Fields, the Meat that Grows on Vines, Cinderella Crop of the Century, the Protein Hope of the Future, and the Amazing Soybean (Rahman, 1978). Nama ini menunjukkan bahwa kedelai adalah bahan pangan yang mengandung nilai gizi tinggi. Kedelai mengandung protein tinggi (Bentley, 1975); kandungan lemak berkualitas tinggi karena mengandung asam lemak esensial linoleat dan linolenat (Schimshaw \& Young, 1976); selain itu, kedelai juga mengandung vitamin dan mineral yang dibutuhkan oleh tubuh (Ferrier, 1975).

\footnotetext{
${ }^{1}$ Staf Pengajar J urusan TP, Faperta - UNAND

2 Staf Pengajar J urusan IKK, FT - UNP

${ }^{3}$ Staf Pengajar Departemen TPG, Fateta - IPB
}

Total produksi kedelai di Indonesia pada tahun 2002 adalah 652755 ton untuk memenuhi kebutuhan konsumsi manusia dan pakan ternak. Untuk kebutuhan tersebut, pemerintah mengimpor dari negara lain terutama USA dan China. Pada tahun 2000 impor kedelai mencapai 593885 ton. Pemanfaatan kedelai untuk makanan di Indonesia paling tinggi di negara ASEAN seperti yang disajikan pada Tabel 1 .

Pada tahun 1987 - 1999 rata-rata asupan energi $1970 \mathrm{Kkal} /$ org/ hari. Hampir 60\%asupan energi berasal dari biji bijian selebihnya berasal dari umbi-umbian, kacang-kacangan, sayuran dan buah-buahan hanya sebagian kecil berasal dari pangan hewani. Bahan-bahan tersebut tidak hanya sebagai sumber energi tetapi juga berfungsi sebagai sumber protein. Tiga jenis bahan pangan sebagai sumber protein utama di Indonesia adalah biji-bijian, kacangkacangan dan ikan. Di antara kacang-kacangan, kedelai merupakan sumber protein yang terpenting. 
Tabel 1. Pemanfaatan Kedelai untuk Makanan di Negara ASEAN

\begin{tabular}{|c|c|c|}
\hline \multirow{2}{*}{ Negara } & 1996 & 1997 \\
\hline & \multicolumn{2}{|c|}{ (1000 MT) } \\
\hline Indonesia & 2100 & 2150 \\
\hline Malaysia & 95 & 100 \\
\hline Philippina & 28 & 28 \\
\hline Singapore & 23 & 24 \\
\hline Thailand & 110 & 110 \\
\hline Vietnam & 101 & 100 \\
\hline Total & 2457 & 2512 \\
\hline
\end{tabular}

Sumber : American Soybean Association (1999)

Tingginya konsumsi bahan pangan nabati adalah akibat rendahnya daya beli masyarakat yang pada akhirnya menyebabkan tingginya prevalensi kurang gizi pada masyarakat berpenghasilan rendah. Untuk meningkatkan status gizi masyarakat yang berpenghasilan rendah perlu ditingkatkan asupan energi dan protein, karena sumber protein yang terpenting pada bahan nabati adalah kedelai, maka untuk itu perlu diteliti bagaimana cara penanganan, penerimaan dan pola konsumsi produk kedelai pada rumahtangga di perkotaan dan di pedesaan.

\section{Tujuan}

Penelitian ini bertujuan untuk mendapatkan data mengenai pengolahan dan penerimaan produk kedelai pada rumahtangga di wilayah pekotaan dan pedesaan Pulau Jawa, Indonesia.

\section{METODE PENELITIAN}

\section{Desain dan Tempat Penelitian}

Penelitian ini menggunakan desain crosssectional study dengan cara survai eksplorasi untuk menggali informasi mengenai cara penanganan/ pengolahan dan penerimaan/ daya terima produk kacang kedelai yang diproduksi secara lokal oleh rumahtangga di Pulau J awa.

Penelitian di dilakukan di Pulau Jawa yang mencakup 6 provinsi yaitu Provinsi DKI J akarta, Provinsi Banten, Provinsi J awa Barat, Provinsi Jawa Tengah, Provinsi Jawa Timur dan Provinsi DI Yogyakarta. Provinsi DKI Jakarta diwakili oleh Kota Jakarta Selatan, Provinsi Banten diwakili oleh Kota Serang dan Kabupaten Tangerang, Provinsi Jawa Barat diwakili oleh Kota Bandung, Kabupaten Bekasi dan Kabupaten Bogor, Provinsi Jawa Tengah diwaliki oleh Kota Solo, Kota Semarang dan Kabupaten Purwokerto, Provinsi Jawa Timur diwakili oleh Kota Surabaya, Kota Malang dan Kabupaten J ember dan Provinsi DI Yogyakarta diwakili oleh Kota Yogyakarta sendiri. Dengan demikian penelitian ini dilakukan di 13 kota/ kabupaten yaitu di 8 kota dan 5 kabupaten yang menggambarkan kondisi wilayah perkotaan dan pedesaan.

\section{Prosedur Penarikan Contoh}

Pemilihan lokasi penelitian (provinsi dan kota/ kabupaten) ditentukan secara purposive dengan alasan bahwa produk kedelai banyak dikonsumsi oleh masyarakat di wilayah tersebut. Dari 13 kota dan kabupaten tersebut, masing-masing dipilih 2 kecamatan secara acak (random) dan dari masing-masing kecamatan dipilih 2 kelurahan/ desa secara acak. Selanjutnya dari masing-masing kelurahan di pilih 2 RW secara acak dan dari masing-masing RW dipilih 2 RT secara acak.

Populasi dalam penelitian ini adalah semua rumahtangga yang berada di 208 RT terpilih yang tersebar di 104 RW, 52 kelurahan, 26 kecamatan, 13 kota/ kabupaten dan 6 provinsi. Unit contoh adalah bapak/suami, ibu/istri, anak-anak dan anggota rumahtangga lainnya seperti orang tua, mertua, ipar, keponakan atau pembantu rumahtangga. Pemilihan contoh tersebut dilakukan secara acak sederhana. Total contoh dalam penelitian ini adalah 2080 rumahtangga.

\section{Jenis dan Cara Pengumpulan Data}

J enis data yang dikumpulkan terdiri dari data sekunder dan primer. Data sekunder terdiri dari data yang secara umum dapat menggambarkan tingkat kesejahteraan masyarakat (golongan miskin dan tidak miskin). Data primer yang dikumpulkan adalah data keadaan sosial ekonomi rumahtangga yang meliputi umur, tingkat pendidikan, jenis pekerjaan, pendapatan dari semua anggota rumahtangga dan ukuran keluarga; cara penanganan/pengolahan produk kedelai dan daya terima produk kedelai yang diwakili oleh kepala rumahtangga dan istri. Data primer tersebut digali dari hasil wawancara menggunakan kuesioner dengan responden (istri dan atau suami).

\section{Pengolahan dan Analisis Data}

Beberapa tahap yang dilakukan dalam pengolahan data adalah merancang struktur data file dengan menggunakan program excel, memberi kode pada kuesioner, pengentrian data, pengujian validitas dan reabilitas data. Pengujian validitas dan reabilitas dilakukan sebelum pengambilan data yang sebenarnya yaitu pada saat dilakukan penelitian pendahuluan pada kelompok yang tidak termasuk sampel. 
Data keadaan sosial ekonomi rumahtangga seperti umur kepala rumahtangga dan istri dihitung dalam tahun, tingkat pendidikan kepala rumahtangga dan istri dilihat dari jumlah tahun mengikuti pendidikan formal, kemudian dikategorikan menurut jenjang pendidikan tidak pernah sekolah, tidak tamat SD, tamat SD, tidak tamat SLTP, tamat SLTP, tidak tamat SLTA, tamat SLTA, Diploma atau Perguruan Tinggi. Jenis pekerjaan suami dan istri dikategorikan PNS, swasta, wiraswasta, TNI/Polri, pensiunan, sopir, tukang ojek, tukang becak, kondektur, buruh, tidak bekerja atau ibu rumahtangga. Data pendapatan rumahtangga merupakan penjumlahan dari pendapatan seluruh anggota keluarga baik dari hasil pekerjaan utama maupun pekerjaan tambahan atau sumber lainnya selama satu bulan. Selanjutnya pendapatan rumahtangga ini dibagi dengan ukuran rumahtangga sehingga diperoleh pendapatan per kapita rumahtangga per bulan kemudian dikategorikan miskin atau tidak miskin. Menurut BPS (2002), rumahtangga di pedesaan dikategorikan miskin apabila jumlah pendapatan per kapita rumahtangga per bulan kurang dari Rp 96 512, lebih dari ketentuan tersebut dikategorikan tidak miskin. Di perkotaan, rumahtangga tergolong miskin apabila pendapatan per kapita rumahtangga per bulannya kurang dari Rp 130 541, lebih dari ketentuan tersebut tergolong tidak miskin.

Cara pengolahan produk kedelai yang dilakukan pada tingkat rumahtangga dikelompokkan seperti ditumis, digoreng, direbus, dikukus, dikonsumsi apa adanya dan dibacem. Daya terima produk kedelai dikategorikan menurut tingkat kesukaan yaitu sangat suka, suka, biasa, tidak suka dan sangat tidak suka. Analisis dilakukan dengan menggunakan program komputer SPSS for Windows. Analisis data yang dilakukan adalah analisis deskriptif dengan menggunakan statistik dasar (elementary statistic analysis), meliputi frekuensi distribusi, dan ukuran sebaran (rata-rata dan standar deviasi).

\section{HASIL DAN PEMBAHASAN}

\section{Keadaan Sosial Ekonomi Rumahtangga}

\section{Umur Kepala Rumahtangga dan Istri}

Di wilayah pedesaan, umur kepala rumah tangga (KRT) berkisar dari 19.0 tahun sampai 77.0 tahun dengan umur rata-rata 35.7 tahun (standar deviasi/ sd = 8.9 tahun), sedangkan di wilayah perkotaan umur KRT berkisar dari 15.7 tahun sampai 86.0 tahun dengan umur ratarata 38.9 tahun ( $s d=10.3$ tahun). Apabila umur KRT dikelompokkan, persentase terbesar (43.3\%) KRT termasuk dalam kelompok umur 30-39 tahun baik di wilayah pedesaan (45.1\%) maupun di perkotaan (42.1\%).

Umur istri di wilayah pedesaan berkisar dari 16.2 tahun sampai 65.0 tahun dengan umur rata-rata 31.2 tahun ( $\mathrm{sd}=7.9$ tahun), sedangkan di wilayah perkotaan umur istri berkisar dari 14.0 tahun sampai 87.0 tahun dengan umur rata-rata 34.7 tahun ( $\mathrm{sd}=10.2$ tahun). Persentase terbesar (47.5\%) umur istri di wilayah pedesaan termasuk kelompok umur 20-29 tahun, sedangkan di wilayah perkotaan persentase terbesar (39.0\%) umur istri termasuk kelompok umur 30-39 tahun.

\section{Pendidikan Kepala Rumahtangga dan Istri}

Lamanya kepala rumahtangga menempuh pendidikan formal di pedesaan berkisar dari 0 tahun (tidak pernah sekolah) sampai 20 tahun dengan lama rata-rata adalah 8.9 tahun ( $s d=4.0$ tahun), sedangkan lamanya kepala rumahtangga menempuh pendidikan di perkotaan berkisar dari 0 tahun (tidak pernah sekolah) sampai 22 tahun dengan lama rata-rata adalah 10.3 tahun ( $s d=3.7$ tahun). Berdasarkan tingkat pendidikan, persentase terbesar kepala rumahtangga di pedesaan dan di perkotaan tergolong berpendidikan tamat SD dan tamat SLTA yaitu masing-masing $24.3 \%$ dan $37.1 \%$

Lamanya istri menempuh pendidikan formal di pedesaan berkisar dari 0 tahun (tidak pernah sekolah) sampai 19 tahun dengan lama rata-rata adalah 8.1 tahun (sd $=3.9$ tahun), sedangkan lamanya istri menempuh pendidikan di perkotaan berkisar dari 0 tahun (tidak pernah sekolah) sampai 22 tahun dengan lama rata-rata adalah 9.5 tahun (sd $=3.6$ tahun). Berdasarkan tingkat pendidikan, persentase terbesar istri di pedesaan dan di perkotaan tergolong berpendidikan tamat SD dan tamat SLTA yaitu masing-masing $29.1 \%$ dan $30.7 \%$

\section{Pekerjaan Kepala Rumahtangga dan Istri}

Sebagian besar kepala rumahtangga bekerja sebagai karyawan swasta (36.0\%) dan wiraswasta (30.7\%) baik di wilayah pedesaan maupun di perkotaan. Namun di pedesaan lebih dominan bekerja sebagai wiraswasta, sedangkan di perkotaan lebih dominan bekerja sebagai pegawai swasta. Hal ini sangat ditentukan oleh lapangan pekerjaan yang ada. Di pedesaan lebih cenderung masyarakat berinisiatif sendiri dalam menciptakan lapangan pekerjaan yang akhirnya menuntut masyarakat untuk berwiraswasta, sedangkan di perkotaan banyak terdapat perkantoran atau perusahaan 
/ pabrik yang menampung tenaga kerja sebagai karyawan swasta.

Pekerjaan utama sebagian besar istri adalah sebagai ibu rumahtangga. Persentase istri yang bekerja sebagai ibu rumahtangga tidak begitu berbeda antara di wilayah pedesaan dengan di wilayah perkotaan dengan nilai masing-masing adalah $88.3 \%$ (pedesaan) dan $84.6 \%$ (perkotaan).

\section{Pendapatan Rumahtangga}

Pendapatan total rumahtangga diperoleh dari pendapatan kepala rumahtangga, istri dan pendapatan dari anggota rumahtangga lainnya seperti anak dan orang tua yang bekerja yang termasuk dalam satu pengelolaan keuangan serta pendapatan dari sumber lain seperti pemberian, bonus dan hadiah. Rata-rata pendapatan total rumahtangga di pedesaan per bulan Rp 1045110.9 (sd = Rp 1734 502.9), sedangkan rata-rata pendapatan rumahtangga di perkotaan lebih besar yaitu Rp 1148 869.1 ( $s d=$ Rpl 340 334.4). Apabila pendapatan total rumahtangga dibagi dengan ukuran rumahtangga, maka diperoleh pendapatan per kapita rumahtangga. Besarnya rata-rata pendapatan per kapita rumahtangga di pedesaan adalah Rp 261437.9 (sd = 437 669.6) dan di perkotaan adalah Rp 284070.1 (sd = Rp 273 600.9).

Batasan garis kemiskinan nasional untuk wilayah pedesaan dan perkotaan menurut BPS (2002) yang dilihat dari rata-rata pendapatan per kapita per bulan adalah Rp 96512 dan Rp 130 541. Berdasarkan batasan tersebut terdapat sebanyak 20.9\% rumahtangga yang tergolong miskin di pedesaan dan $20.3 \%$ di perkotaan.

\section{Cara Pengolahan Produk Kedelai di Rumah- tangga}

Produk kedelai yang biasa ditemui di pasaran dan dikonsumsi penduduk Indonesia khususnya di Pulau Jawa adalah berupa tempe, tauco, kecap kedelai, tahu, kembang tahu, tauge kedelai, kacang kedelai, oncom dan gembus. Banyak cara yang dilakukan di tingkat rumahtangga dalam menangani/ mengolah produk kedelai tersebut sebelum dikonsumsi. Cara-cara penanganan/pengolahan produk kedelai yang umum dilakukan di rumahtangga adalah ditumis, digoreng, direbus, dikukus dan dibacem. Ada juga produk kedelai tersebut yang dibuat kerupuk dan pergedel. Selain itu ada juga produk kedelai yang langsung dimakan apa adanya di rumahtangga yang sebelumnya telah diolah di pabrik. Rata-rata waktu yang digunakan di rumahtangga dalam pengolahan produk kedelai cukup bervariasi, ter- gantung pada cara pengolahan dan jumlah produk yang diolah.

Lebih dari $50.0 \%$ rumahtangga di pedesaan mengolah tempe, tauco dan tahu dengan cara ditumis dengan rata-rata lamanya waktu yang digunakan dalam mengolah berkisar antara 11.8-15.9 menit. Produk kedelai yang diolah dengan cara ditumis oleh lebih dari 50.0\% rumahtangga di perkotaan adalah tempe, tahu dan tauge kedelai dengan rata-rata lamanya waktu pengolahan yang dibutuhkan berkisar antara 11.0-16.7 menit.

Sebagian besar produk kedelai yang diolah di rumahtangga pedesaan dengan cara digoreng adalah tempe, tahu dan kacang kedelai, sedangkan di rumahtangga perkotaan adalah tempe dan tahu saja. Rata-rata lamanya waktu yang digunakan dalam menggoreng produk pangan tersebut di rumahtangga perkotaan lebih sedikit dibandingkan dengan yang digunakan oleh rumahtangga pedesaan

Di wilayah pedesaan, kurang dari $50.0 \%$ rumahtangga yang melakukan pengolahan produk kedelai dengan cara direbus, sementara di perkotaan ada lebih dari $50.0 \%$ rumahtangga mengolahnya dengan cara direbus yaitu untuk produk tempe dan tahu. Secara umum ratarata waktu yang digunakan di pedesaan dalam mengolah produk kedelai dengan cara direbus lebih lama dibandingkan waktu yang digunakan di perkotaan.

Di wilayah pedesaan, jenis produk kedelai yang diolah dengan cara dikukus lebih terbatas dibandingkan di perkotaan yaitu hanya pada produk tempe, tahu, tauge kedelai, kacang kedelai dan oncom. Namun rata-rata lamanya waktu yang digunakan dalam mengolah dengan cara dikukus ini lebih lama di perkotaan dibanding di pedesaan. Rumahtangga yang mengolah produk kedelai dengan cara dikukus ini hanya sebagian kecil saja (kurang dari 50.0\% rumahtangga).

Di perkotaan juga terdapat jenis produk kedelai lainnya yang diolah dengan cara dibacem yaitu oncom dan gembus. Dalam pembuatan bacem biasanya juga digunakan kecap yang berfungsi untuk membuat hasil olahan berwarna kecoklatan dan memberi rasa gurih pada produk yang dibacem.

Ada beberapa produk kedelai yang biasa dikonsumsi apa adanya (tidak diolah) di rumahtangga yaitu kecap kedelai, tauge kedelai dan susu kedelai. Persentase rumahtangga di pedesaan (82.6\%) yang mengonsumsi kecap kedelai secara apa adanya tidak berbeda nyata dengan rumahtangga di perkotaan (81.1\%). Namun untuk produk susu kedelai, rumah- 
tangga di perkotaan lebih banyak yang mengonsumsinya dibandingkan dengan rumahtangga di pedesaan. Terdapat juga sebagian kecil rumahtangga di perkotaan yang mengolah tahu dengan dibuat pergedel.

\section{Daya Terima Produk Kedelai}

Daya terima anggota rumahtangga terhadap produk kedelai yang biasa dikonsumsi dikelompokkan ke dalam 6 kategori yaitu tidak suka, kurang suka, biasa saja, suka, sangat suka dan belum pernah mengonsumsi. Adapun anggota rumahtangga yang dibahas dalam penelitian ini yaitu kepala rumahtangga dan istri.

\section{Kepala Rumahtangga}

Lebih dari 90.0\% kepala rumahtangga di pedesaan dan di perkotaan menyatakan suka dan sangat suka terhadap tempe, sedangkan kesukaan terhadap tauco masih rendah seperti terlihat pada Tabel 2.

Sebagian besar (71.4\%) kepala rumahtangga di pedesaan menyatakan suka terhadap kecap kedelai, bahkan sebanyak $16.5 \%$ sangat menyukainya. Demikian juga dengan tahu seperti terlihat pada Tabel 3.

Daya terima kepala rumahtangga terhadap susu kedelai masih rendah. Hal ini disebabkan karena sebagian besar kepala rumahtangga di pedesaan dan di perkotaan belum pernah mengonsumsi susu kedelai.

Tabel 2. Daya Terima Kepala Rumahtangga terhadap Tempe dan Tauco menurut Wilayah

\begin{tabular}{|c|c|c|c|c|c|c|c|}
\hline \multirow{3}{*}{ Produk Kedelai } & \multirow{3}{*}{ Daya Terima } & \multicolumn{6}{|c|}{ Kategori Wilayah } \\
\hline & & \multicolumn{2}{|c|}{ Pedesaan } & \multicolumn{2}{|c|}{ Perkotaan } & \multicolumn{2}{|c|}{ Total } \\
\hline & & $\mathbf{n}$ & $\%$ & $\mathbf{n}$ & $\%$ & $\mathbf{n}$ & $\%$ \\
\hline \multirow{7}{*}{ Tempe } & Tidak suka & 1 & 0.1 & 4 & 0.3 & 5 & 0.2 \\
\hline & Kurang suka & 9 & 1.1 & 16 & 1.3 & 25 & 1.2 \\
\hline & Biasa saja & 38 & 4.8 & 57 & 4.5 & 95 & 4.6 \\
\hline & Suka & 563 & 71.0 & 578 & 45.5 & 1141 & 55.3 \\
\hline & Sangat suka & 181 & 22.8 & 613 & 48.3 & 794 & 38.5 \\
\hline & Belum pernah mengonsumsi & 1 & 0.1 & 2 & 0.2 & 3 & 0.1 \\
\hline & Total & 793 & 100.0 & 1270 & 100.0 & 2063 & 100.0 \\
\hline \multirow[t]{7}{*}{ Tauco } & Tidak suka & 118 & 14.9 & 68 & 5.4 & 186 & 9.0 \\
\hline & Kurang suka & 55 & 6.9 & 126 & 9.9 & 181 & 8.8 \\
\hline & Biasa saja & 56 & 7.1 & 129 & 10.2 & 185 & 9.0 \\
\hline & Suka & 302 & 38.0 & 155 & 12.2 & 457 & 22.2 \\
\hline & Sangat suka & 17 & 2.1 & 44 & 3.5 & 61 & 3.0 \\
\hline & Belum pernah mengonsumsi & 246 & 31.0 & 747 & 58.9 & 993 & 48.1 \\
\hline & Total & 794 & 100.0 & 1269 & 100.0 & 2063 & 100.0 \\
\hline
\end{tabular}

Tabel 3. Daya Terima Kepala Rumahtangga terhadap Kecap Kedelai dan Tahu menurut Wilayah

\begin{tabular}{|c|c|c|c|c|c|c|c|}
\hline \multirow{3}{*}{ Produk Kedelai } & \multirow{3}{*}{ Daya Terima } & \multicolumn{6}{|c|}{ Kategori Wilayah } \\
\hline & & \multicolumn{2}{|c|}{ Pedesaan } & \multicolumn{2}{|c|}{ Perkotaan } & \multicolumn{2}{|c|}{ Total } \\
\hline & & $\mathbf{n}$ & $\%$ & $\mathbf{n}$ & $\%$ & $\mathbf{n}$ & $\%$ \\
\hline \multirow{7}{*}{ Kecap Kedelai } & Tidak suka & 17 & 2.1 & 23 & 1.8 & 40 & 1.9 \\
\hline & Kurang suka & 26 & 3.3 & 60 & 4.7 & 86 & 4.2 \\
\hline & Biasa saja & 52 & 6.5 & 338 & 26.6 & 390 & 18.9 \\
\hline & Suka & 567 & 71.4 & 579 & 45.6 & 1146 & 55.6 \\
\hline & Sangat suka & 131 & 16.5 & 266 & 21.0 & 397 & 19.2 \\
\hline & Belum pernah mengonsumsi & 1 & 0.1 & 3 & 0.2 & 4 & 0.2 \\
\hline & Total & 794 & 100.0 & 1269 & 100.0 & 2063 & 100.0 \\
\hline \multirow[t]{7}{*}{ Tahu } & Tidak suka & 6 & 0.8 & 2 & 0.2 & 8 & 0.4 \\
\hline & Kurang suka & 13 & 1.6 & 16 & 1.3 & 29 & 1.4 \\
\hline & Biasa saja & 33 & 4.2 & 67 & 5.3 & 100 & 4.8 \\
\hline & Suka & 597 & 75.2 & 645 & 50.8 & 1242 & 60.2 \\
\hline & Sangat suka & 143 & 18.0 & 536 & 42.2 & 679 & 32.9 \\
\hline & Belum pernah mengonsumsi & 2 & 0.3 & 3 & 0.2 & 5 & 0.2 \\
\hline & Total & 794 & 100.0 & 1269 & 100.0 & 2063 & 100.0 \\
\hline
\end{tabular}


Kondisi rendahnya daya terima kepala rumahtangga terhadap susu kedelai hampir sama dengan kembang tahu. Hal ini disebabkan karena sebagian besar kepala rumahtangga di pedesaan dan di perkotaan belum pernah mengonsumsi kembang tahu tersebut. Persentase terbesar (46.2\%) kepala rumahtangga di pedesaan dan sebanyak $42.2 \%$ di perkotaan menyatakan suka terhadap toge dele. Daya terima kacang kedelai (biji) cukup tinggi di pedesaan yaitu sebanyak 63.9\% kepala rumahtangga di pedesaan menyukai dan bahkan terdapat $6.3 \%$ yang sangat suka dengan kacang kedelai. Di perkotaan, terdapat sebanyak $36.9 \%$ kepala rumahtangga yang suka dengan kacang kedelai, sebanyak 5.1\% sangat suka dan 28.1\% menyatakan biasa-biasa saja kesukaannya terhadap kacang kedelai. Biasanya kacang kedelai (biji) yang telah digoreng dikonsumsi bersamaan dengan mengonsumsi bubur ayam, salah satu pilihan menu sarapan pagi yang banyak dikonsumsi penduduk Pulau Jawa.

Oncom yang terbuat dari ampas tahu banyak dan mudah diperoleh di Pulau Jawa terutama di Jawa Barat, DKI Jakarta dan Banten. Sementara gembus banyak dan mudah diperoleh khususnya di Provinsi J awa Tengah, Yogyakarta dan Jawa Timur. Sebanyak 49.7\% kepala rumahtangga di pedesaan menyatakan suka pada oncom, sedangkan kepala rumahtangga di perkotaan yang suka oncom relatif lebih sedikit yaitu $27.7 \%$

\section{Istri}

Daya terima istri terhadap tempe sangat tinggi yaitu sekitar $95.0 \%$ istri di pedesaan maupun di perkotaan menyukai produk kedelai berupa tempe, sedangkan tauco kurang disukai (Tabel 4).

Sebagian besar (76.1\%) istri di pedesaan menyatakan suka terhadap kecap kedelai, bahkan sebanyak $15.7 \%$ sangat menyukainya. Hanya sebagian kecil saja (4.6\%) istri yang tidak dan kurang menyukai kecap kedelai. Di perkotaan, persentase terbesar (47.1\%) istri menyatakan suka terhadap kecap kedelai, bahkan sebanyak $19.9 \%$ sangat menyukainya. Namun terdapat sebanyak $19.6 \%$ istri di pedesaan dan perkotaan yang menyatakan kesukaannya terhadap kecap kedelai biasa-biasa saja seperti terlihat pada Tabel 5.

Secara umum pada Tabel 5 juga terlihat bahwa lebih dari $90.0 \%$ istri di pedesaan dan di perkotaan menyatakan suka dan sangat suka terhadap tahu. Hal ini ditunjukkan dengan hasil bahwa sebanyak $76.3 \%$ istri di pedesaan menyatakan suka dan bahkan sebanyak 18.8\% sangat suka terhadap tahu. Hal yang sama juga terlihat di perkotaan bahwa sebanyak 50.6\% istri menyatakan suka dan $42.7 \%$ sangat suka terhadap tahu. Hanya sebagian kecil saja dari istri di pedesaan dan di perkotaan yang belum pernah mengonsumsi tahu.

Daya terima istri terhadap susu kedelai masih rendah. Hal ini disebabkan karena sebagian besar istri di pedesaan dan di perkotaan belum pernah mengonsumsi susu kedelai. Sebanyak $65.6 \%$ istri di pedesaan dan $43.6 \%$ di perkotaan menyatakan belum pernah mengonsumsi susu kedelai. Hanya sebagian kecil saja yang menyatakan menyukai produk kedelai tersebut, yang lain menyatakan biasa-biasa saja dan terdapat sekitar $14.7 \%$ yang tidak dan kurang menyukai susu kedelai.

Tabel 4. Daya Terima Istri terhadap Tempe dan Tauco menurut Wilayah

\begin{tabular}{|c|c|c|c|c|c|c|c|}
\hline \multirow{3}{*}{ Produk Kedelai } & \multirow{3}{*}{ Daya Terima } & \multicolumn{6}{|c|}{ Kategori Wilayah } \\
\hline & & \multicolumn{2}{|c|}{ Pedesaan } & \multicolumn{2}{|c|}{ Perkotaan } & \multicolumn{2}{|c|}{ Total } \\
\hline & & $\mathbf{n}$ & $\%$ & $\mathbf{n}$ & $\%$ & $\mathbf{n}$ & $\%$ \\
\hline \multirow{7}{*}{ Tempe } & Tidak suka & 1 & 0.1 & 2 & 0.2 & 3 & 0.1 \\
\hline & Kurang suka & 2 & 0.3 & 5 & 0.4 & 7 & 0.3 \\
\hline & Biasa saja & 34 & 4.3 & 64 & 5.0 & 98 & 4.7 \\
\hline & Suka & 579 & 72.6 & 611 & 47.7 & 1190 & 57.2 \\
\hline & Sangat suka & 181 & 22.7 & 598 & 46.7 & 779 & 37.5 \\
\hline & Belum pernah mengonsumsi & 1 & 0.1 & 1 & 0.1 & 2 & 0.1 \\
\hline & Total & 798 & 100.0 & 1281 & 100.0 & 2079 & 100.0 \\
\hline \multirow[t]{7}{*}{ Tauco } & Tidak suka & 102 & 12.8 & 48 & 3.8 & 150 & 7.2 \\
\hline & Kurang suka & 48 & 6.0 & 101 & 7.9 & 149 & 7.2 \\
\hline & Biasa saja & 57 & 7.1 & 136 & 10.6 & 193 & 9.3 \\
\hline & Suka & 327 & 41.0 & 200 & 15.6 & 527 & 25.4 \\
\hline & Sangat suka & 15 & 1.9 & 54 & 4.2 & 69 & 3.3 \\
\hline & Belum pernah mengonsumsi & 249 & 31.2 & 741 & 57.9 & 990 & 47.6 \\
\hline & Total & 798 & 100.0 & 1280 & 100.0 & 2078 & 100.0 \\
\hline
\end{tabular}


Tabel 5. Daya Terima Istri terhadap Kecap Kedelai dan Tahu menurut Wilayah

\begin{tabular}{|c|c|c|c|c|c|c|c|}
\hline \multirow{3}{*}{ Produk Kedelai } & \multirow{3}{*}{ Daya Terima } & \multicolumn{6}{|c|}{ Kategori Wilayah } \\
\hline & & \multicolumn{2}{|c|}{ Pedesaan } & \multicolumn{2}{|c|}{ Perkotaan } & \multicolumn{2}{|c|}{ Total } \\
\hline & & $n$ & $\%$ & $n$ & $\%$ & $n$ & $\%$ \\
\hline \multirow[t]{7}{*}{ Kecap Kedelai } & Tidak suka & 12 & 1.5 & 17 & 1.3 & 29 & 1.4 \\
\hline & Kurang suka & 25 & 3.1 & 55 & 4.3 & 80 & 3.8 \\
\hline & Biasa saja & 60 & 7.5 & 347 & 27.1 & 407 & 19.6 \\
\hline & Suka & 575 & 72.1 & 603 & 47.1 & 1178 & 56.7 \\
\hline & Sangat suka & 125 & 15.7 & 255 & 19.9 & 380 & 18.3 \\
\hline & Belum pernah mengonsumsi & 1 & 0.1 & 3 & 0.2 & 4 & 0.2 \\
\hline & Total & 798 & 100.0 & 1280 & 100.0 & 2078 & 100.0 \\
\hline \multirow[t]{7}{*}{ Tahu } & Tidak suka & 4 & 0.5 & 2 & 0.2 & 6 & 0.3 \\
\hline & Kurang suka & 6 & 0.8 & 9 & 0.7 & 15 & 0.7 \\
\hline & Biasa saja & 27 & 3.4 & 73 & 5.7 & 100 & 4.8 \\
\hline & Suka & 609 & 76.3 & 648 & 50.6 & 1257 & 60.5 \\
\hline & Sangat suka & 150 & 18.8 & 546 & 42.7 & 696 & 33.5 \\
\hline & Belum pernah mengonsumsi & 2 & 0.3 & 2 & 0.2 & 4 & 0.2 \\
\hline & Total & 798 & 100.0 & 1280 & 100.0 & 2078 & 100.0 \\
\hline
\end{tabular}

Kondisi rendahnya daya terima istri terhadap susu kedelai hampir sama dengan kembang tahu. Hal ini disebabkan karena sebagian besar istri di pedesaan dan di perkotaan belum pernah mengonsumsi kembang tahu tersebut. Sebanyak $47.0 \%$ istri di pedesaan dan $44.7 \%$ di perkotaan menyatakan suka terhadap toge dele. Hanya sebagian kecil saja (8.6\%) istri di pedesaan dan $12.8 \%$ di perkotaan yang tidak atau kurang menyukai toge dele. Persentase istri di pedesaan yang belum pernah mengonsumsi toge dele cukup besar yaitu sebanyak $24.8 \%$ Sementara di perkotaan, sebanyak $24.3 \%$ istri menyatakan biasabiasa saja daya terimanya terhadap toge dele.

Daya terima kacang kedelai (biji) cukup tinggi di pedesaan yaitu sebanyak $63.5 \%$ istri di pedesaan menyatakan suka dan bahkan terdapat $5.8 \%$ yang sangat suka dengan kacang kedelai. Di perkotaan, terdapat sebanyak $37.3 \%$ istri yang suka dengan kacang kedelai, sebanyak $5.0 \%$ sangat suka dan $27.8 \%$ menyatakan biasa-biasa saja kesukaannya terhadap kacang kedelai.

Sama halnya dengan kepala rumahtangga, biasanya istri mengonsumsi kacang kedelai (biji) yang telah digoreng bersamaan dengan mengonsumsi bubur ayam yaitu salah satu pilihan menu yang banyak dikonsumsi penduduk Pulau Jawa.

Sebanyak $50.6 \%$ istri di pedesaan menyatakan suka pada oncom, sedangkan istri di perkotaan yang suka oncom relatif lebih sedikit yaitu $30.3 \%$ Persentase istri yang belum pernah mengonsumsi oncom masih cukup tinggi baik di pedesaan maupun di perkotaan.

\section{KESIMPULAN DAN SARAN}

\section{Kesimpulan}

1. J enis produk kedelai yang banyak ditemui di pasaran dan dikonsumsi penduduk Indonesia khususnya di Pulau Jawa baik diperkotaan maupun pedesaan adalah berupa tempe, tauco, kecap kedelai, tahu, kembang tahu, toge dele, kacang kedelai, oncom dan gembus. Cara-cara pengolahan produk kedelai yang umum dilakukan di rumahtangga adalah ditumis, digoreng, direbus, dikukus dan dibacem. Produk kedelai yang sering diolah dengan cara ditumis seperti tempe, tauco, tahu, kembang tahu, toge dele, oncom dan gembus. Produk kedelai yang sering diolah rumahtangga dengan cara digoreng seperti, tempe, tahu, kacang kedelai (biji), oncom dan gembus. Produk kedelai yang sering diolah dengan cara direbus atau di sayur seperti tempe, tahu dan kembang tahu. Produk kedelai yang sering diolah dengan cara dikukus adalah tahu dan yang sering diolah dengan cara dibacem adalah tempe dan tahu. Selain itu ada juga produk kedelai yang langsung dimakan apa adanya di rumahtangga yang sebelumnya telah diolah di pabrik seperti kecap kedelai dan susu kedelai. Rata-rata waktu yang digunakan di rumahtangga dalam pengolahan produk kedelai cukup bervariasi, tergantung pada cara pengolahan dan jumlah produk yang diolah.

2. Lebih dari $90.0 \%$ kepala rumahtangga di pedesaan dan di perkotaan menyatakan suka dan sangat suka terhadap tempe dan tahu. Kurang dari 50.0\% kepala rumahtangga di pedesaan dan perkotaan yang menyukai tauco, toge dele, oncom dan 
gembus. Sekitar 70.0\%kepala rumahtangga di pedesaan dan perkotaan menyatakan suka terhadap kecap kedelai. Daya terima kepala rumahtangga terhadap susu kedelai dan kembang tahu masih rendah. Daya terima kepala rumahtangga terhadap kacang kedelai (biji) cukup tinggi di pedesaan yaitu sekitar $70.0 \%$ sedangkan di perkotaan sekitar $40.0 \%$ Daya terima istri terhadap tempe, kecap kedelai dan tahu sangat tinggi yaitu lebih dari 90.0\% Daya terima istri terhadap tauco, susu kedelai, kembang tahu, toge dele, oncom dan gembus masih rendah yaitu kurang dari $50.0 \%$ Daya terima istri di pedesaan dan di perkotaan terhadap kacang kedelai sekitar $60.0 \%$

\section{Saran}

Produsen susu kedelai perlu mengevaluasi proses produksi susunya supaya produk susunya terasa lebih enak dan tidak langu. Di samping itu, produsen susu kedelai perlu memperluas jaringan pemasaran sampai ke desadesa.

\section{DAFTAR PUSTAKA}

American Soybean Association (ASA). 1999. Southeast Asia Soyfoods Directory 19992000. ASA, Singapore.

Bentley OG. 1975. Soybeans and People. Proc. of Conf. for Scientists of Africa, the
Middle East and South Asia, Series No. 6, 2-6.

Biro Pusat Statistik (BPS). 2002. Indikator Kesejahteraan Rakyat. BPS, J akarta.

Ferrier LK. 1975. Simple Processing of Whole Soybeans. Proc. of Conf. for Scientists of Africa, the Middle East and South Asia, Series No. 6, 2-6.

Handajani S. 2001. Indigenous mucuna tempe as functional food. Asia Pacific J. Clin. Nutr., 10(3), 222-225.

Koswara S. 1992. Teknologi Pengolahan Kedelai Menjadikan Makanan Bermutu. Pustaka Sinar Harapan, J akarta.

Rahman L. 1978. Soya Protein Foods in Bangladesh: An Analysis of Prospects and Constraints. Proc. Intl. Soya Prot. Food Conf., Singapore, 13-17

Scrimshaw NS \& R Young. 1976. The Requirement of Human Nutrition. Scientific American, 235(3), 51-64.

Silitonga C. 1986. Pemasaran dan Penanganan Pascapanen J agung dan Kedelai. Konsultasi Teknis Pengembangan Industri Pengolahan Jagung dan Kedelai. Balitbang Industri-Departemen Perindustrian dan Pusbangtepa-IPB, Bogor. 